\title{
Keratin, Type I Cytoskeletal 20
}

National Cancer Institute

\section{Source}

National Cancer Institute. Keratin, Type I Cytoskeletal 20. NCI Thesaurus. Code C96459.

Keratin, type I cytoskeletal 20 (424 aa, $\sim 48$ kDa) is encoded by the human KRT 20 gene.

This protein plays a role in the organization of keratins in the intestinal epithelium. 